\title{
KESAHAN KANDUNGAN MODUL LITERASI AWAL (MODUL LIT-A) PADA PERINGKAT KANAK-KANAK BERUMUR 2+, 3+ DAN 4+ TAHUN
}

\author{
Content Validity of Early Literacy Module (Modul Lit-A) for Children Aged 2+, 3+, And 4+ \\ Years
}

Zainiah Mohamed Isa ${ }^{1}$, Juppri Bacotang ${ }^{2}$, Mazlina Che Mustafa ${ }^{3}$

Fakulti Pembangunan Manusia, Universiti Pendidikan Sultan Idris

35900 Tanjong Malim, Perak.

zainiah@fpm.upsi.edu.my ${ }^{1}$, juppri@fpm.upsi.edu.my ${ }^{2}$, mazlina.cm@fpm.upsi.edu.my ${ }^{3}$

\begin{abstract}
ABSTRAK
Kajian ini menjelaskan kesahan kandungan Modul Literasi Awal (Modul Lit-A) pada peringkat kanak-kanak berumur 2+, 3+, dan 4+ tahun di Malaysia. Modul Lit-A dibangunkan berdasarkan reka bentuk pengajaran model ADDIE yang memfokuskan kemahiran literasi awal dalam Bahasa Melayu seperti bahasa dan komunikasi, konsep cetakan dan cetakan persekitaran, fonemik dan fonetik, bacaan dan kefahaman naratif, dan tulisan awal. Modul LitA terdiri daripada tiga set yang berlainan mengikut umur kanak-kanak iaitu 2+, 3+, dan 4+ tahun. Kajian ini berbentuk kuantitatif yang menggunakan kaedah tinjauan untuk mendapatkan pandangan pakar melalui soal selidik berkaitan kandungan Modul Lit-A. Sampel kajian terdiri daripada 12 orang pakar bagi Modul Lit-A (2+ Tahun), 10 orang pakar bagi Modul Lit-A (3+ Tahun), dan 8 orang pakar bagi Modul Lit-A (4+ Tahun). Dapatan kajian menunjukkan Modul Lit-A (2+, 3+, dan 4+ Tahun) mempunyai kesahan kandungan yang tinggi. Justeru, Modul LitA boleh dijadikan sumber tambahan kepada ibu bapa atau pendidik untuk memberi pendedahan tentang kemahiran literasi awal terhadap kanak-kanak berumur 2+, 3+, dan 4+ tahun. Ini seterusnya dapat menyokong dan melengkapkan lagi kurikulum pendidikan awal kanak-kanak yang sedia ada di Malaysia.
\end{abstract}

Kata Kunci: kemahiran literasi awal, Modul Lit-A, kesahan kandungan, awal kanak-kanak

\begin{abstract}
This study explains contents validity of the Early Literacy Module (Modul Lit-A) for children aged 2+, 3+, and 4+ years in Malaysia. The Modul Lit-A is developed based on ADDIE model of teaching that focuses on early literacy skills in Malay such as language and communication, print concept and environmental print, phonemic and phonetic, narrative reading and comprehension, and early writing. The Modul Lit-A consists of three different sets of children's aged 2+, 3+, and 4+ years. The study was quantitative using the survey method to get an expert view through a questionnaire related to Modul Lit-A content. The research sample consists of 12 experts for the Modul Lit-A (2+ Years), 10 experts for the Modul Lit-A (3+Years), and 8 experts for the Modul Lit-A (4+Years). The findings show that the Modul Lit-A $(2+, 3+$, and 4+ Years) have high content validity. Thus, the Modul Lit-A can be used as an additional resource for parents or educators to provide exposure on early literacy skills for children aged 2+, 3+, and 4+ years. This in turn will support and complement the existing early childhood education curriculum in Malaysia.
\end{abstract}

Keywords: early literacy skills, Modul Lit-A, content validity, early childhood

\section{PENGENALAN}

Teori pemunculan literasi 'emergent literacy' telah dikemukakan oleh Clay (1966) yang bermaksud proses perkembangan pertuturan, membaca, dan menulis yang berlaku sejak lahir dan berterusan sehingga kanak-kanak memperoleh kemahiran membaca dan menulis yang 
sebenar. Menurut Dunst, Trivette, Masiello, Roper, dan Robyak (2006), kanak-kanak berumur $2+$ tahun berada pada tahap pemunculan literasi, manakala kanak-kanak berumur $3+$ dan $4+$ tahun berada pada tahap literasi awal. Dalam kajian ini, pengkaji menggunakan istilah kemahiran literasi awal yang merujuk pada tingkah laku, konsep, dan kemahiran yang sedia ada sejak awal usia kanak-kanak lagi; dan dikembangkan menjadi literasi yang merangkumi bacaan, tulisan biasa, dan pengetahuan sastera pada masa hadapan (Machado, 2016; Moravcik, Nolte, \& Feeney, 2013).

Kemahiran literasi awal juga mempunyai komponen tertentu seperti yang terdapat dalam kemahiran komunikasi seperti mendengar, bertutur, membaca, dan menulis (Beaty, 2013; Mahzan, 2012). Namun, komponen dalam kemahiran literasi awal menggunakan istilah yang lebih spesifik, iaitu; (i) bahasa dan komunikasi; (ii) konsep cetakan dan cetakan persekitaran; (iii) fonemik dan fonetik; (iv) bacaan dan kefahaman naratif; dan (v) tulisan awal. Kesemua komponen ini diperoleh berdasarkan perbandingan beberapa teori dan kurikulum berkaitan kemahiran literasi awal (Juppri \& Zainiah, 2015).

Kemahiran literasi awal sangat penting kepada kanak-kanak kerana merupakan faktor peramal terbaik yang dapat menentukan tahap penguasaan membaca dan menulis mereka pada masa hadapan (National Early Literacy Panel, 2008; Snow, Burns, \& Griffin, 1998; Whitehurst \& Lonigan, 1998). Walau bagaimanapun, pendidik tidak mempunyai sumber atau pengetahuan yang mencukupi untuk melaksanakan aktiviti yang dapat meningkatkan kemahiran literasi awal kanak-kanak (Gober, 2008). Ini disokong oleh Aliza dan Zamri (2016) yang mendapati pendidik memerlukan sumber dan bahan yang sesuai untuk merangsang pembelajaran bahasa murid seperti pembangunan sebuah modul yang memperincikan cara mengajar kemahiran bahasa menggunakan pendekatan bermain yang merangkumi aspek-aspek seperti langkah-langkah terperinci, kaedah, teknik, peruntukan masa, cadangan permainan dan cadangan bahan permainan yang bersesuaian.

Modul pengajaran dan pembelajaran (PdP) kemahiran literasi awal yang terdapat di Malaysia adalah terhad dan hanya difokuskan dalam kurikulum yang bersifat holistik terhadap semua aspek perkembangan kanak-kanak seperti Kurikulum PERMATA Negara (Bahagian PERMATA, 2013) dan Kurikulum Standard Prasekolah Kebangsaan: Semakan 2017 (Kementerian Pelajaran Malaysia, 2016). Juppri (2012) telah membangunkan sebuah modul PdP kemahiran literasi awal yang dikenali sebagai Modul Literasi Awal (MULA), namun modul tersebut hanya memfokuskan tiga komponen dalam kemahiran literasi awal iaitu kesedaran fonologikal, pengetahuan cetakan dan tulisan awal bagi kanak-kanak berumur 4 tahun sahaja. Sehingga kini, masih belum ada modul PdP kemahiran literasi awal yang spesifik dan lengkap untuk kanak-kanak berumur 4 tahun ke bawah.

Usaha untuk meningkatkan tahap kemahiran literasi awal kanak-kanak memerlukan suatu modul PdP yang spesifik dan menyeluruh. Justeru, Zainiah, Juppri, Mahzan, Ainon, dan Mazlina (2016) telah membangunkan Modul Literasi Awal (Modul Lit-A). Pembangunan Modul Lit-A adalah berdasarkan reka bentuk pengajaran model ADDIE (Analysis, Design, Development, Implementation, dan Evaluation) yang diperkenalkan oleh Rossett (1987). Model ADDIE adalah antara model reka bentuk pengajaran yang digunakan sebagai panduan dalam proses pembangunan sesuatu modul (Saedah, Norlidah, DeWitt, \& Zaharah, 2013). Modul Lit-A dibangunkan untuk memberi pendedahan kepada kanak-kanak berumur 2+, 3+, dan 4+ tahun tentang kemahiran literasi awal dalam Bahasa Melayu seperti bahasa dan komunikasi, konsep cetakan dan cetakan persekitaran, fonemik dan fonetik, bacaan dan kefahaman naratif, dan tulisan awal. 
Modul Lit-A mengandungi dua bahagian utama iaitu; (i) pengenalan yang menjelaskan tentang kemahiran literasi awal, komponen dalam kemahiran literasi awal, senarai aktiviti, panduan pelaksanaan aktiviti dan kesimpulan; dan (ii) aktiviti bagi setiap komponen dalam kemahiran literasi awal. Setiap aktiviti tersebut dibina dalam bentuk rancangan pelaksanaan aktiviti (RPA) yang mengandungi maklumat seperti jenis komponen kemahiran literasi awal, objektif pembelajaran, bahan bantu mengajar, langkah-langkah pelaksanaan aktiviti, aktiviti pengukuhan dan pengayaan, dan dokumen sokongan.

Modul Lit-A terdiri daripada tiga set yang berlainan mengikut umur kanak-kanak, iaitu 2+, $3+$, dan 4+ tahun supaya bersesuaian dengan pengetahuan, pengalaman, dan minat mereka. Jumlah aktiviti bagi setiap set Modul Lit-A adalah sebanyak 25 aktiviti untuk kanak-kanak berumur 2+ tahun, 43 aktiviti untuk untuk kanak-kanak berumur 3+ tahun, dan 46 aktiviti untuk untuk kanak-kanak berumur 4+ tahun. Justeru, kajian ini dijalankan untuk menjelaskan kesahan kandungan bagi Modul Lit-A yang diperoleh daripada ahli pakar.

\section{METODOLOGI}

Kajian ini berbentuk kuantitatif yang menggunakan kaedah tinjauan untuk mengenal pasti kesahan kandungan Modul Lit-A. Kesahan merujuk pada sejauh mana sesuatu instrumen atau alat dapat mengukur perkara yang sepatutnya diukur (Anastasi \& Urbina, 1997). Kesahan juga merupakan indikator ketepatan kajian iaitu sama ada kajian tersebut memberi gambaran yang benar tentang fenomena yang dikaji (Othman, 2014). Noraini (2013) menyatakan kesahan yang tinggi menunjukkan dapatan yang diperoleh adalah berdasarkan fakta atau bukti dan mampu memberi justifikasi yang tepat.

Sesuatu alat atau instrumen pengukuran adalah sah apabila pembinaan alat itu memenuhi atau menetapi fungsi dan objektif pembinaannya. Alat pengukuran dianggap sama maksud dengan modul kerana alat ukuran dan modul merupakan alat, sumber, bahan yang menjadi panduan kepada pengkaji untuk mendapatkan pelbagai maklumat berkaitan dengan kajian yang dilakukan (Sidek \& Jamaludin 2005). Ini disokong oleh Md Noor, Nurul Ain dan Norazani (2016) yang menyatakan kesahan modul merujuk pada ketepatan konsep dan kandungan sesuatu modul.

Dalam kajian ini, pengkaji hanya menjalankan kesahan kandungan bagi Modul Lit-A bagi memastikan kandungan Modul Lit-A adalah tepat dan berkualiti. Ini kerana kesahan kandungan merupakan penilaian sistematik terhadap kualiti kandungan sesuatu modul (Anastasi \& Urbina, 1997). Bagi meningkatkan kesahan kandungan, pengkaji perlu mendapatkan pandangan dan maklum balas daripada pakar untuk menilai dan memastikan domain-domain yang terkandung dalam sesuatu modul mewakili bidang kajian (Noraini, 2013). Kumpulan pakar merupakan mereka yang mempunyai kepakaran, pengalaman dan kesesuaian dengan modul yang dibangunkan oleh pengkaji. Kriteria pemilihan kepakaran dalam kajian ini adalah seperti berikut; (i) kepakaran dan pengetahuan berkaitan dengan bidang PAKK; (ii) kepakaran dan pengetahuan dalam bidang perkembangan bahasa dan komunikasi kanak-kanak, dan (iii) pengamal dalam bidang PAKK.

Justeru, pengkaji melibatkan 12 orang pakar bagi Modul Lit-A (2+ Tahun), 10 orang pakar bagi Modul Lit-A (3+ Tahun), dan 8 orang pakar bagi Modul Lit-A (4+ Tahun) sebagai sampel kajian. Ini bertepatan dengan saranan Mohd (1999) yang menjelaskan penilaian sesuatu modul 
memerlukan enam hingga sembilan orang pakar seperti yang telah dijalankan dalam kajian lain (Aliza \& Zamri, 2016; Mahzam, 2013; Md Noor et al., 2016; Mohammad Aziz Shah, Md. Noor, Samsiah, Aslina, \& Nurul Yakin, 2014; Rozman \& Ahmad Jazimin, 2015). Maklumat diri ahli pakar bagi kesahan kandungan setiap set Modul Lit-A ditunjukkan dalam Jadual 1 seperti berikut;

Jadual 1: Maklumat Diri Ahli Pakar bagi Kesahan Kandungan Modul Lit-A (2+, 3+, dan 4+ Tahun)

\begin{tabular}{|c|c|c|c|c|}
\hline \multirow[b]{2}{*}{ Perkara } & \multirow[b]{2}{*}{ Kategori } & \multicolumn{3}{|c|}{ Modul Lit-A } \\
\hline & & $2+$ Tahun & 3+ Tahun & 4+ Tahun \\
\hline Tahap Kelayakan & Doktor Pendidikan & 1 & 1 & 1 \\
\hline \multirow[t]{6}{*}{ Akademik } & Sarjana & 2 & 1 & 3 \\
\hline & Sarjana Muda & 4 & 4 & 0 \\
\hline & Diploma & 1 & 1 & 3 \\
\hline & STPM & 1 & 0 & 0 \\
\hline & SPM & 3 & 3 & 1 \\
\hline & Jumlah & 12 & 10 & 8 \\
\hline \multirow[t]{3}{*}{ Jawatan } & Pensyarah & 2 & 2 & 2 \\
\hline & Pendidik & 10 & 8 & 6 \\
\hline & Jumlah & 12 & 10 & 8 \\
\hline \multirow[t]{6}{*}{ Organisasi } & Universiti & 4 & 4 & 4 \\
\hline & PAPN & 3 & 1 & 0 \\
\hline & KEMAS & 1 & 2 & 1 \\
\hline & JPNIN & 0 & 0 & 1 \\
\hline & Swasta & 4 & 3 & 2 \\
\hline & Jumlah & 12 & 10 & 8 \\
\hline
\end{tabular}

Nota: STPM (Sijil Tinggi Pelajaran Malaysia), SPM (Sijil Pelajaran Malaysia), PAPN (Pusat Anak PERMATA Negara), KEMAS (Jabatan Kemajuan Masyarakat), JPNIN (Jabatan Perpaduan Negara dan Integriti Nasional)

Instrumen yang digunakan dalam kajian ini ialah satu set soal selidik kesahan kandungan modul yang diubahsuai daripada Russell (1974) untuk mendapatkan kesahan kandungan secara keseluruhan bagi Modul Lit-A. Menurut Russel (1974), item kesahan kandungan modul mempunyai lima perkara, iaitu; (i) menepati sasaran populasi; (ii) kaedah pelaksanaan modul adalah bersesuaian; (iii) masa yang diperuntukkan untuk menjalankan modul adalah mencukupi; (iv) modul berjaya meningkatkan pencapaian pelajar dalam aspek yang disasarkan; dan (v) modul berjaya mengubah sikap pelajar ke arah yang lebih cemerlang. Selain itu, soal selidik tersebut juga menilai kesahan kandungan bagi setiap aktiviti yang terdapat dalam Modul Lit-A. Kesemua item dalam soal selidik tersebut adalah berdasarkan skala penilaian lima mata pilihan, iaitu 1 (Sangat Tidak Sesuai) hingga 5 (Sangat Sesuai).

Pengkaji telah menyediakan satu salinan lengkap Modul Lit-A dan satu set soal selidik kesahan kandungan modul kepada setiap pakar untuk meneliti, menilai, dan memberi cadangan penambahbaikan bagi kandungan Modul Lit-A. Modul yang mempunyai kesahan kandungan yang tinggi akan menghasilkan pencapaian mengikut objektif yang ingin diukur oleh pengkaji (Md Noor et al., 2016). Menurut Tuckman dan Waheed (1981); dan Sidek dan Jamaludin (2005), pencapaian 70 peratus dianggap mencapai tahap kesahan kandungan yang tinggi yang diperoleh berdasarkan formula berikut;

$$
\frac{\text { Jumlah Skor Pakar }}{\text { Skor maksimum }} \quad \text { X } 100 \%=\text { Pencapaian Kesahan Kandungan }
$$




\section{DAPATAN KAJIAN}

Dapatan kajian terdiri daripada; (i) kesahan kandungan secara keseluruhan bagi Modul Lit-A berdasarkan soal selidik kesahan kandungan modul Russell (1974) yang telah diubahsuai oleh pengkaji; dan (ii) kesahan kandungan bagi setiap aktiviti yang terdapat dalam Modul Lit-A mengikut umur kanak-kanak iaitu 2+, 3+, dan 4+ tahun. Pengkaji juga mengumpulkan dan membandingkan cadangan penambahbaikan yang diperoleh daripada ahli pakar secara bertulis.

\section{Kesahan Kandungan secara Keseluruhan bagi Modul Lit-A (2+, 3+, dan 4+ Tahun)}

Berdasarkan Jadual 2, kesahan kandungan secara keseluruhan bagi Modul Lit-A (2+ Tahun) adalah tinggi iaitu sebanyak 85.6 peratus. Pengkaji mendapati peratus kesahan kandungan yang paling rendah ialah 75.6 peratus bagi item "Aktiviti menggunakan pendekatan dan teknik PdP yang kreatif, menarik, dan sesuai untuk kanak-kanak.", manakala peratus kesahan kandungan yang paling tinggi ialah 90.0 peratus bagi item "Aktiviti mempunyai langkah-langkah mengikut urutan yang mudah difahami, jelas dan sesuai untuk kanak-kanak.”.

Kesahan kandungan secara keseluruhan bagi Modul Lit-A (3+ Tahun) juga adalah tinggi iaitu sebanyak 84.9 peratus. Pengkaji mendapati peratus kesahan kandungan yang paling rendah ialah 82.0 peratus bagi item "Aktiviti mempunyai langkah-langkah mengikut urutan yang mudah difahami, jelas dan sesuai untuk kanak-kanak.", manakala peratus kesahan kandungan yang paling tinggi ialah 90.0 peratus bagi item "Aktiviti melibatkan kanak-kanak dengan aktif, seronok, selesa, dan selamat.".

Kesahan kandungan secara keseluruhan bagi Modul Lit-A (4+ Tahun) juga adalah tinggi iaitu sebanyak 83.4 peratus. Pengkaji mendapati peratus kesahan kandungan yang paling rendah ialah 80.0 peratus bagi item "Aktiviti menggunakan pendekatan dan teknik PdP yang kreatif, menarik, dan sesuai untuk kanak-kanak." dan "Aktiviti mempunyai objektif pembelajaran yang yang tepat dan sesuai untuk kanak-kanak.", manakala peratus kesahan kandungan yang paling tinggi ialah 88.6 peratus bagi item "Aktiviti melibatkan kanak-kanak dengan aktif, seronok, selesa, dan selamat."

Jadual 2: Kesahan Kandungan secara Keseluruhan bagi Modul Lit-A (2+, 3+, dan 4+ Tahun)

\begin{tabular}{llccc}
\hline \multicolumn{1}{c}{ Item } & \multicolumn{3}{c}{ Modul Lit-A / Peratus (\%) } & Pandangan \\
& 2+ Tahun & 3+ Tahun & 4+ Tahun & Pakar \\
\hline 1. $\begin{array}{l}\text { Aktiviti bersesuaian dengan } \\
\text { pengetahuan, kemahiran, dan } \\
\text { pengalaman kanak-kanak. } \\
\text { Aktiviti menggunakan pendekatan dan } \\
\text { teknik PdP yang kreatif, menarik, dan } \\
\text { sesuai untuk kanak-kanak. }\end{array}$ & 86.6 & 84.0 & 85.8 & Diterima \\
3. & 75.6 & 84.4 & 80.0 & Diterima \\
$\begin{array}{l}\text { Aktiviti mempunyai langkah-langkah } \\
\text { mengikut urutan yang mudah difahami, } \\
\text { jelas dan sesuai untuk kanak-kanak. } \\
\text { Aktiviti mempunyai objektif } \\
\text { pembelajaran yang yang tepat dan }\end{array}$ & 90.0 & 82.0 & 82.6 & Diterima \\
$\begin{array}{l}\text { sesuai untuk kanak-kanak. } \\
\text { Aktiviti melibatkan kanak-kanak } \\
\text { dengan aktif, seronok, selesa, dan } \\
\text { selamat. }\end{array}$ & 87.2 & 84.0 & 80.0 & Diterima \\
Keseluruhan & 88.4 & 90.0 & 88.6 & Diterima \\
\hline
\end{tabular}




\section{Kesahan Kandungan bagi Aktiviti Modul Lit-A (2+ Tahun)}

Berdasarkan Jadual 3, kesahan kandungan secara keseluruhan bagi aktiviti Modul Lit-A (2+ Tahun) adalah tinggi iaitu 84.6 peratus. Pengkaji mendapati peratus kesahan kandungan yang paling rendah ialah 75.6 peratus bagi aktiviti "Simbol Tandas", manakala peratus kesahan kandungan yang paling tinggi ialah 92.0 peratus bagi aktiviti "Capan Tapak Tangan".

Jadual 3: Kesahan Kandungan bagi Aktiviti Modul Lit-A (2+ Tahun)

\begin{tabular}{llcc}
\hline \multicolumn{1}{c}{ Komponen } & \multicolumn{1}{c}{ Nama Aktiviti } & Peratus (\%) & Pandangan Pakar \\
\hline Bahasa dan & 1. Cermin Oh Cermin & 91.6 & Diterima \\
komunikasi & 2. Cantuman Muka & 85.0 & Diterima \\
& 3. Perasaan Saya & 78.2 & Diterima \\
& 4. Kucing Comel & 84.4 & Diterima \\
& 5. Bahagian Kereta & 86.0 & Diterima \\
Konsep Cetakan dan & 6. Kenali Bunyi Saya & 86.6 & Diterima \\
Cetakan Persekitaran & 7. Buku Adik & 84.4 & Diterima \\
& 8. Cerita Keluarga Saya & 78.2 & Diterima \\
& 9. Haiwan di Ladang & 91.6 & Diterima \\
Fonemik dan Fonetik & 10. Memilih Makanan & 80.0 & Diterima \\
& 11. Simbol Tandas & 75.6 & Diterima \\
& 12. Bunyi Kenderaan & 83.6 & Diterima \\
& 13. Ikut Rentak Muzik & 88.8 & Diterima \\
& 14. Lagu 'Bangun Pagi' & 90.0 & Diterima \\
15. Lagu 'Abu Ada Ayam' & 80.0 & Diterima \\
16. Membuat Huruf 's' & 82.6 & Diterima \\
Kefaan dan & 17. Susun Buku & 86.6 & Diterima \\
& 18. Ayuh, Belek Buku & 83.4 & Diterima \\
& 19. Semut yang Rajin & 86.0 & Diterima \\
20. Adam Ada Bola & 78.2 & Diterima \\
21. Penggembala dan Biri-biri & 82.0 & Diterima \\
Tulisan Awal & 22. Garisan Mudah & 85.0 & Diterima \\
& 23. Muka 'Smiley' & 83.4 & Diterima \\
& 24. Capan Tapak Tangan & 92.0 & Diterima \\
Keseluruhan & 25. Kapas Berwarna & 91.0 & Diterima \\
\hline
\end{tabular}

\section{Kesahan Kandungan bagi Aktiviti Modul Lit-A (3+ Tahun)}

Berdasarkan Jadual 4, kesahan kandungan secara keseluruhan bagi aktiviti Modul Lit-A (3+ Tahun) juga adalah tinggi iaitu 85.7 peratus. Pengkaji mendapati peratus kesahan kandungan yang paling rendah ialah 72.0 peratus bagi aktiviti "Mari Membaca", manakala peratus kesahan kandungan yang paling tinggi ialah 95.6 peratus bagi aktiviti "Siapa Saya?".

Jadual 4: Kesahan Kandungan bagi Aktiviti Modul Lit-A (3+ Tahun)

\begin{tabular}{|c|c|c|c|}
\hline Komponen & Nama Aktiviti & Peratus (\%) & Pandangan Pakar \\
\hline Bahasa dan & 1. Kenali Badan Anda & 88.0 & Diterima \\
\hline \multirow{5}{*}{ komunikasi } & 2. Kenderaan Darat & 88.0 & Diterima \\
\hline & 3. Apa Emosi Saya? & 84.0 & Diterima \\
\hline & 4. Kucing Comel & 86.6 & Diterima \\
\hline & 5. Nak Dengar Cerita? & 88.0 & Diterima \\
\hline & 6. Robot $\mathrm{Ku}$ & 84.4 & Diterima \\
\hline
\end{tabular}




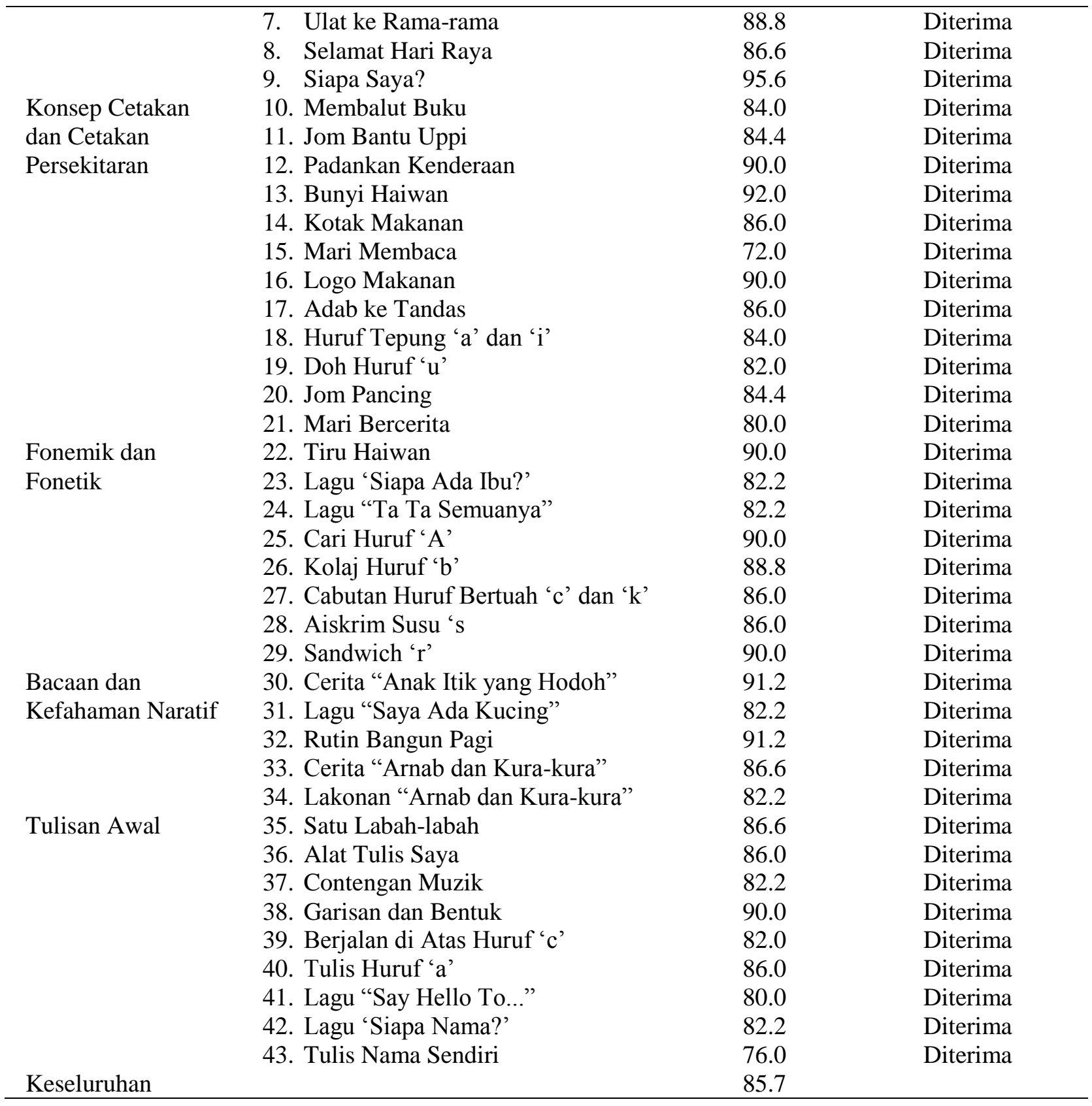

\section{Kesahan Kandungan bagi Aktiviti Modul Lit-A (4+ Tahun)}

Berdasarkan Jadual 5, kesahan kandungan secara keseluruhan bagi aktiviti Modul Lit-A (4+ Tahun) juga adalah tinggi iaitu 85.3 peratus. Pengkaji mendapati peratus kesahan kandungan yang paling rendah ialah 74.2 peratus bagi aktiviti "Ayat Saya" dan "Rasa Sayang", manakala peratus kesahan kandungan yang paling tinggi ialah 91.4 peratus bagi aktiviti "Tiket Bas".

Jadual 5: Kesahan Kandungan bagi Aktiviti Modul Lit-A (4+ Tahun)

\begin{tabular}{|c|c|c|c|}
\hline Komponen & Nama Aktiviti & Peratus (\%) & Pandangan Pakar \\
\hline Bahasa dan & 1. Kawan Saya & 87.6 & Diterima \\
\hline \multirow[t]{3}{*}{ komunikasi } & 2. Huruf Pertama & 85.0 & Diterima \\
\hline & 3. Emosi Saya & 77.6 & Diterima \\
\hline & 4. Ahli Keluarga Saya & 88.6 & Diterima \\
\hline
\end{tabular}




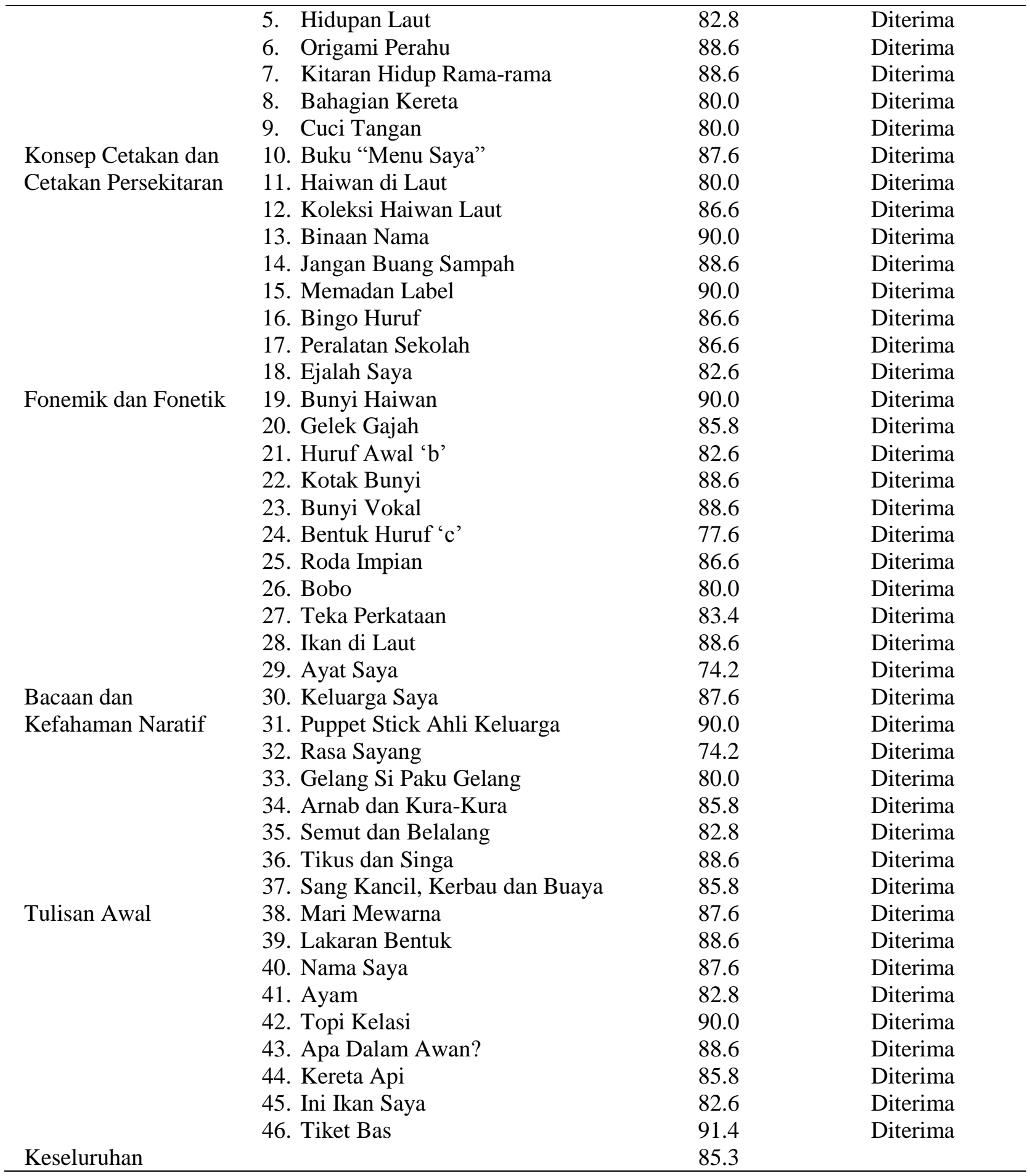

\section{Cadangan Penambahbaikan bagi Modul Lit-A (2+, 3+, dan 4+ Tahun)}

Pengkaji juga telah mengumpulkan dan membandingkan cadangan penambahbaikan yang diberikan oleh ahli secara bertulis seperti dalam Jadual 6. Berdasarkan cadangan penambahbaikan tersebut, pengkaji telah menjalankan pemurnian Modul Lit-A (2+, 3+, dan 4+ Tahun) supaya lebih tepat dan sempurna. 
Jadual 6: Cadangan Penambahbaikan Modul Lit-A (2+, 3+, dan 4+ Tahun) daripada Ahli Pakar

\begin{tabular}{|c|c|c|c|c|}
\hline \multirow[b]{2}{*}{ No. } & \multirow[b]{2}{*}{ Cadangan Penambahbaikan } & \multicolumn{3}{|c|}{$\begin{array}{c}\text { Bilangan Ahli Pakar yang Memberikan } \\
\text { Cadangan }\end{array}$} \\
\hline & & $2+$ Tahun & 3+ Tahun & 4+ Tahun \\
\hline 1. & $\begin{array}{l}\text { Buku panduan perlu panduan perlu disediakan bagi setiap } \\
\text { set Modul Lit-A dengan jelas dan mudah difahami oleh } \\
\text { pendidik. }\end{array}$ & 1 & 2 & 2 \\
\hline 2. & $\begin{array}{l}\text { Aktiviti perlu bersesuaian dengan pengetahuan, kemahiran, } \\
\text { dan pengalaman kanak-kanak. }\end{array}$ & 7 & 5 & 4 \\
\hline 3. & $\begin{array}{l}\text { Aktiviti perlu menggunakan tema yang pelbagai dan sesuai } \\
\text { untuk kanak-kanak. }\end{array}$ & 2 & 1 & 1 \\
\hline 4. & $\begin{array}{l}\text { Aktiviti perlu mempunyai objektif pembelajaran yang tepat, } \\
\text { spesifik, dan sesuai untuk kanak-kanak. }\end{array}$ & 3 & 3 & 3 \\
\hline 5. & $\begin{array}{l}\text { Aktiviti perlu menggunakan bahan bantu mengajar yang } \\
\text { kreatif, menarik, mencukupi, pelbagai, dan sesuai untuk } \\
\text { kanak-kanak. }\end{array}$ & 3 & 3 & 2 \\
\hline 6. & $\begin{array}{l}\text { Aktiviti perlu menekankan beberapa kosa kata yang jelas, } \\
\text { sesuai, dan bermakna untuk kanak-kanak. }\end{array}$ & 1 & 1 & 2 \\
\hline 7. & $\begin{array}{l}\text { Aktiviti perlu mempunyai langkah-langkah (arahan) } \\
\text { mengikut urutan dari mudah ke susah, jelas dan sesuai untuk } \\
\text { kanak-kanak. }\end{array}$ & 2 & 6 & 3 \\
\hline 8. & $\begin{array}{l}\text { Aktiviti perlu menggunakan pendekatan dan teknik PdP } \\
\text { yang kreatif, menarik, 'hands on' dan sesuai untuk kanak- } \\
\text { kanak. }\end{array}$ & 3 & 3 & 3 \\
\hline 9. & $\begin{array}{l}\text { Aktiviti perlu melibatkan kanak-kanak dengan aktif, } \\
\text { seronok, selesa, dan selamat. }\end{array}$ & 2 & 3 & 3 \\
\hline 10. & $\begin{array}{l}\text { Aktiviti perlu mempunyai pengayaan yang dapat mencabar } \\
\text { kebolehan kanak-kanak. }\end{array}$ & 1 & 1 & 3 \\
\hline
\end{tabular}

\section{PERBINCANGAN}

Kajian ini menunjukkan Modul Lit-A untuk kanak-kanak berumur 2+, 3+, dan 4+ tahun mempunyai kesahan kandungan yang tinggi. Ini bermakna, domain-domain yang terkandung dalam Modul Lit-A adalah sesuai dan mewakili bidang kemahiran literasi awal untuk kanakkanak. Modul Lit-A juga boleh dianggap sebagai modul yang lengkap kerana telah melalui prosedur reka bentuk pengajaran model ADDIE dan mempunyai kesahan kandungan yang tinggi. Ini kerana modul yang bermutu dan dianggap lengkap setelah diuji kesahan kandungannya (Md Noor et al., 2016).

Kajian ini juga telah berjaya mewujudkan satu kerangka teoritikal yang komprehensif dalam pendekatan kemahiran literasi awal. Teori pemunculan literasi yang dikemukakan oleh Clay (1966) telah dijadikan asas dalam pembangunan Modul Lit-A berdasarkan prosedur model ADDIE. Ini adalah selari dengan Goldstein dan Olszewskia (2015) yang menjalankan kajian pembangunan modul dengan melalui prosedur yang berurutan dan sistematik.

Oleh itu, Modul Lit-A boleh dijadikan sebagai bahan sokongan utama kepada pendidik bagi mengajar kanak-kanak kemahiran literasi awal dengan lebih efisien dan optimum. Ini kerana setiap aktiviti Modul Lit-A dihasilkan dalam bentuk RPA dapat membantu pendidik dalam proses PdP (Aliza \& Zamri, 2016; Syazwani \& Faridah, 2015). Menurut Davis (2014), pengajaran pendidik perlu disokong melalui latihan, bantuan bahan, dan pengalaman positif bersama dengan kanak-kanak. Ini bertepatan dengan Lovelace (2010) yang menyatakan 
pendidik perlu mengubahsuai strategi pengajaran supaya bersesuaian dengan keperluan individu kanak-kanak.

Selain itu, Modul Lit-A dapat menyokong dan melengkapkan lagi kurikulum PAKK yang sedia ada di Malaysia. Ini kerana Modul Lit-A mempunyai perkaitan dan kesinambungan dengan Kurikulum PERMATA Negara dalam Perkembangan Bahasa, Komunikasi dan Literasi Awal (Bahagian PERMATA, 2013); dan Kurikulum Standard Prasekolah Kebangsaan: Semakan 2017 dalam Tunjang Komunikasi (Kementerian Pelajaran Malaysia, 2016). Ini selari dengan kajian lain yang mendapati pembangunan modul PdP yang baharu dapat diaplikasikan dan diintegrasikan dalam kurikulum yang sedia ada (Ling \& Hasnah, 2010; Mazlini, Aminah, Ong, Mohd Nasir, Noriah, \& Jameyah, 2016).

\section{PENUTUP}

Kajian ini membuktikan modul PdP kemahiran literasi awal untuk kanak-kanak boleh dibangunkan secara empirikal berdasarkan prosedur pembangunan modul yang sistematik seperti model ADDIE. Pengkaji berjaya membangunkan Modul Lit-A yang spesifik dan lengkap untuk kanak-kanak berumur 2+, 3+, dan 4+ tahun. Dapatan kesahan kandungan Modul Lit-A yang tinggi daripada penilai pakar menunjukkan kandungan Modul Lit- A adalah sah dan berkualiti. Justeru, pengkaji berharap penggunaan Modul Lit-A dapat diperluaskan kepada ibu bapa atau pendidik untuk memberi pendedahan kemahiran literasi awal terhadap kanak-kanak di Malaysia.

\section{PENGHARGAAN}

Kajian ini mendapat dana daripada Kementerian Pengajian Tinggi (KPT) melalui Skim Geran Penyelidikan Fundamental (FRGS), Kod Penyelidikan: 2013-0062-107-02.

\section{RUJUKAN}

Aliza Ali, \& Zamri Mahamod. (2016). Pembangunan dan kebolehgunaan modul berasaskan bermain bagi pembelajaran kemahiran Bahasa Melayu kanak-kanak prasekolah, Jurnal Pendidikan Bahasa Melayu, 6(1), 16-29.

Anastasi, A., \& Urbina, S. (1997). Psychological testing. Upper Saddle River: Prentice-Hall.

Bahagian PERMATA. (2013). Kurikulum PERMATA Negara: Asuhan dan didikan awal kanak-kanak 04 tahun (Cetakan Ketiga). Cyberjaya, Selangor: Jabatan Perdana Menteri.

Beaty, J. J. (2013). 50 early chilhood literacy strategies (3rd ed.). Upper Saddle River, NJ: Pearson Education.

Clay, M. M. (1966). Emergent reading behavior. Unpublished doctoral dissertation, University of Auckland, New Zealand.

Davis, D., L. (2014). Fidelity of implementation, teacher perceptions and child outcomes of a literacy curriculum in a Head Start program: A mixed methods study. Disertasi doktor falsafah yang tidak diterbitkan, University of Nebraska, United State.

Dunst, C. J., Trivette, C. M., Masiello, T., Roper, N., \& Robyak, A. (2006). Framework for developing evidence-based early literacy learning practices. Center for Early Literacy Learning, 5(1), 1-15.

Gober, M. C. (2008). Concepts about print (CAP) and the development of early reading strategies in kindergarten. Unpublished doctoral dissertation, Walden University, Minneapolis, MN. 
Goldstein, H., \& Olszewskia, A. (2015). Developing a phonological awareness curriculum: Reflections on an implementation science framework. Journal of Speech, Language, and Hearing Research, Vol. $58,1837-1850$.

Juppri Bacotang, \& Zainiah Mohamed Isa. (2015). Pembangunan kerangka Kurikulum Awal Literasi (KUALITI) untuk kanak-kanak TASKA di Malaysia. Kertas kerja yang dibentangkan dalam Seminar Kebangsaan Pendidikan Negara (SKEPEN), Universiti Kebangsaan Malaysia, Nilai, Negeri Sembilan.

Juppri Bacotang. (2012). Kesan pelaksanaan aktiviti Modul Literasi Awal (MULA) terhadap kemahiran literasi awal kanak-kanak TASKA. Tesis sarjana pendidikan yang tidak diterbitkan, Universiti Pendidikan Sultan Idris, Tanjong Malim, Perak.

Kementerian Pelajaran Malaysia. (2016). Kurikulum Standard Prasekolah Kebangsaan: Dokumen standard kurikulum dan pentaksiran. Kuala Lumpur: Bahagian Pembangunan Kurikulum.

Ling, P. K., \& Hasnah Toran. (2010). Pelaksanaan aktiviti seni kreatif dalam pendidikan prasekolah Malaysia. Diperoleh semula daripada http://file.upi.edu/Direktori/JURNAL/EDUCATIONIST/Vol._IV_No._1Januari_2010/06_Ling_Pik_ Kuong_dan_Hasnah_Toran.pdf

Lovelace, F. A. (2010). An examination of early literacy in an early childhood classroom. Unpublished Doctor of Education dissertation, The University of Memphis, United State.

Machado, J. M. (2016). Early childhood experiences in language arts: Early literacy (11th ed.). Boston, MA: Cengage Learning.

Mahzam Mohd Saad. (2013). Kesan pendekatan kognitif tingkah laku dalam kaunseling kelompok terhadap kebimbangan sosial dan perhatian fokus kendiri remaja. Tesis doktor falsafah yang tidak diterbitkan, Universiti Malaya, Kuala Lumpur.

Mahzan Arshad. (2012). Pendidikan literasi awal kanak-kanak: Teori dan amali. Tanjong Malim, Perak: Penerbit Universiti Pendidikan Sultan Idris.

Mazlini Adnan, Aminah Ayob, Ong Eng Tek, Mohd Nasir Ibrahim, Noriah Ishak, \& Jameyah Sheriff. (2016). Memperkasa pembangunan modal insan Malaysia di peringkat kanak-kanak: Kajian kebolehlaksanaan dan kebolehintegrasian pendidikan STEM dalam Kurikulum PERMATA Negara. Malaysian Journal of Society and Space, Vol. 12(1), 29-36.

Md Noor Saper, Nurul Ain Mohd Daud, \& Norazani Ahmad. (2016). Kesahan dan kebolehpercayaan Modul I-Sc (Islamic Spiritual Counseling) ke atas pelajar bermasalah tingkah laku. International Journal of Islamic Thought, Vol. 9, 32-43.

Mohammad Aziz Shah Mohamed Arip, Md. Noor Saper, Samsiah Jais, Aslina Ahmad, \& Nurul Yakin Supeni. (2014). Pembinaan kesahan dan kebolehpercayaan Modul Transfromasi Ehsan Pusat Perlidungan Wanita Baitul Ehsan, Sabak Bernam, Geran Penyelidikan MAIS.

Mohd Najib. (1999). Penyelidikan pendidikan. Johor Darul Takzim: Penerbit Universiti Teknologi Malaysia.

Moravcik, E., Nolte, S., \& Feeney, S. (2013). Meaningful curriculum for young children. Upple Saddle River, NJ: Pearson Education, Inc.

National Early Literacy Panel. (2008). Developing early literacy. Washington, DC: National Institute for Literacy.

Noraini Idris. (2013). Penyelidikan dalam pendidikan (edisi kedua). Kuala Lumpur: McGraw Hill Education (Malaysia) Sdn. Bhd.

Othman Lebar. (2014). Penyelidikan kualitatif: Pengenalan kepada teori dan metode. Tanjong Malim, Perak: Penerbit Universiti Pendidikan Sultan Idris.

Rossett, A. (1987). Training needs assessment. Englewood Cliffs: Educational Technology Publications.

Rozman Salleh, \& Ahmad Jazimin Jusoh. (2015). Kesahan dan kebolehpercayaan soal selidik egogram analisis transaksional dalam kalangan pelajar sekolah menengah. Jurnal PERKAMA, Vol. 19, 67-82.

Rusell, J. D. (1974). Modular instruction: A guide to the design, selection, utilization and evaluation of modular materials. United States: Publishing Company

Saedah Siraj, Norlidah Alias, DeWitt, D., \& Zaharah Hussin. (2013). Design and developmental research: Emergent trends in educational research. Kuala Lumpur: Pearson Malaysia Sdn. Bhd.

Sidek Mohd Noah, \& Jamaludin Ahmad. (2005). Pembinaan Modul: Bagaimana Membina Modul Latihan dan Modul Akademik. Serdang: Penerbit Universiti Putra Malaysia. 
Snow, C., Burns, S., \& Griffin, P. (1998). Preventing reading difficulties in young children. Washington, DC: National Academy Press.

Syazwani Hussin, \& Faridah Yunus. (2015). Pengadaptasian Modul Pra Literasi bahasa Inggeris sebagai bahasa kedua, Prosiding Seminar Kebangsaan Pendidikan Negara Kali Ke-5, 657-669.

Tuckman, B. W., \& Waheed, M. A. (1981). Evaluating an individualized science programmed for community college student. Journal of Research in Science Teaching, 18, 489-495.

Whitehurst, J. G., \& Lonigan, C. (1998). Child development and emergent literacy. Child Development, 69, 848-872.

Zainiah Mohamed Isa, Juppri Bacotang, Mahzan Arsyad, Ainon Omar, \& Mazlina Che Mustafa. (2016). Pembinaan sebuah modul untuk pecutan penguasaan asas literasi bagi kanak-kanak berumur 2+, 3+, dan 4+ tahun. Universiti Pendidikan Sultan Idris, Tanjong Malim, Perak. 